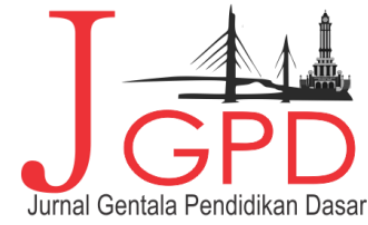

Research Article

\title{
Penggunaan Media Big Book untuk Meningkatkan Kemampuan Berpikir Kritis Siswa di Kelas V Sekolah Dasar
}

Issaura Sherly Pamela, Suci Hayati, Rila Suci Insani

Program Studi Pendidikan Guru Sekolah Dasar, FKIP, Universitas Jambi, Jambi, Indonesia

\section{Article Information}

Reviewed : Nov 30, 2019

Revised : Dec 20, 2019

Available Online : Dec 30, 2019

\section{Keyword \\ Berpikir Kritis, Media, Big Book}

\section{Corespondence}

e-mail :

issaurasherly@gmail.com

\section{ABSTRACT}

This study aims to improve students' critical thinking skills by using big book media in class V of SD Negeri 13/1 Rengas Condong in the academic year 2017/2018. This research is a classroom action research (CAR), data taken through observation. This research was conducted in 4 stages, namely Planning, Implementation, Observation, and Reflection. During the process of learning activities using the big book media. The instrument used in this study was in the form of tests and observation sheets, while the benchmarks for the tests were critical thinking indicators, while the benchmarks for observation sheets were critical thinking features using the big book media. The results of this study indicate the use of big book media can improve the critical thinking skills of fifth grade students at SD Negeri 13/1 Rengas Condong. Based on the observation sheet and the test of students' critical thinking skills showed an increase, with the results of the observation sheet percentage of the first cycle of $61.4 \%$ with a fairly good category, on the second cycle of $77 \%$ with a good category, while the percentage of the results of the first cycle of the test was $45.5 \%$, in the second cycle increased by $81 \%$. Based on the results of the study, it can be concluded that students' critical thinking skills by using big books in SD Negeri 13/1 Rengas Condong can increase after the use of big book media is applied.

\section{DOI : https://doi.org/10.22437/gentala.v4i2.8456}

\section{PENDAHULUAN}

Pendidikan adalah kegiatan terencana dalam pelaksanaan proses pembelajaran agar siswa secara aktif mampu mengembangkan potensi dirinya untuk memiliki kekuatan dalam menghadapi masa depan seperti, pengendalian diri, kepribadian, kecerdasan, akhlak mulia, serta keterampilan yang diperlukan dirinya. "pendidikan berfungsi untuk mempersiapkan manusia menghadapi masa depan agar hidup lebih sejahtera, baik sebagai individu maupun secara kolektif sebagai warga masyarakat, bangsa maupun antar bangsa" (Umedi, Dkk 2009:1.3).

Berdasarkan uraian pendapat di atas dapat disimpulkan bahwa pendidikan merupakan tempat bagi siswa untuk mengembangkan kemampuan yang di milikinya, baik kognitif 


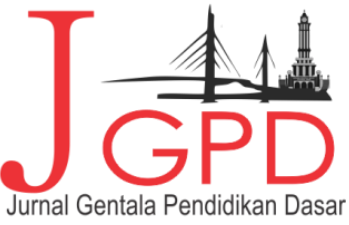

JURNAL GENTALA PENDIDIKAN DASAR Vol 4.No.2 December 2019 Page 245-263

P-ISSN : 2614-7092, E-ISSN : 2621-966II

Available Cnline at Web : http://online-journal.unja.ac.id/index.php/gentala email : penyunting.jurnal.g-pgsd国unja.ac.id

maupun psikomotorik, dan pendidikan juga merupakan tempat sebagai proses mengubah tingkah laku serta cara berpikir siswa ke arah yang lebih baik, melalui pendidikan siswa diharapkan dapat menjadi manusia dewasa yang mampu menghadapi masa depan, untuk mencapai hal tersebut guru sebaiknya mampu mengetahui karakteristik siswa.

Karakteristik siswa merupakan salah satu kompetensi yang harus dikuasai oleh seorang guru. Apabila guru memahami karateristik siswa maka guru dapat memberikan pembelajaran yang sesuai dengan karakteristik dan kemampuan yang di milikinya. Karakteristik siswa kelas $\mathrm{V}$ sekolah dasar ialah memiliki rasa ingin tahu yang tinggi, mencoba, gemar menyelidiki, dan mempunyai kemampuan memahami dan berpikir sesuai kenyataan. Pada usia ini siswa berada pada tahap operasional konkret dimana mereka sudah mulai memahami aspek-aspek komulatif materi pembelajaran.

Karakteristik pada siswa kelas V yaitu memiliki kemampuan memahami dan berpikir sesuai kenyataan. Menurut Syah (2015:123) “ berpikir rasional dan kritis adalah perwujudan perilaku belajar terutama yang bertalian dengan pemecahan masalah". Kemampuan berpikir kritis sangat penting bagi siswa karena berpikir kritis menggunakan pikiran yang cepat dan tepat dalam menanggapi permasalahan, untuk membangkitkan hal tersebut perlu adanya dorongan dari guru pada saat proses pembelajaran seperti desain pembelajaran yang menarik dan kreatif, tidak membosankan sehingga mampu merangsang kemapuan berpikirnya, hal tersebut sering kali bertentangan dengan kenyataan yang dilihat dari beberapa sekolah dasar dalam kegiatan pembelajaran.

Berdasarkan hasil observasi awal yang dilakukan pada tanggal 06 Oktober 2017 di SD Negeri 13/I Rengas Condong. Pada siswa kelas V yang berjumlah 22 orang, 13 orang perempuan dan 9 orang laki-laki. Peneliti melihat dan menemukan masalah melalui proses pembelajaran yang berlangsung di kelas V E SDN 13/I Rengas Condong ada beberapa masalah yang ditemukan di kelas $\mathrm{V}$ ini yaitu dalam proses pembelajaran siswa terlihat pasif cenderung hanya mendengarkan tanpa bertanya atau bisa disebut siswa kurang aktif dalam bertanya, siswa juga kurang peka terhadap pertanyaan, rasa ingin tahu siswa rendah, dan saat diberikan tugas latihan siswa mengerjakan hanya asal-asalan saja. Kemudian peneliti melakukan observasi di kelas $\mathrm{V}$ tersebut dengan menggunakan lembar observasi karakteristik kemampuan berpikir kritis. Ternyata memang benar proses pembelajaran kemampuan berpikir kritis siswa memang rendah. Hal ini terbukti saat observasi hanya $19 \%$ yang mampu memenuhi karakteristik kemampuan berpikir kritis siswa. Peneliti melihat penyebab dari 


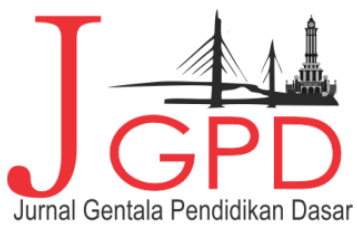

JURNAL GENTALA PENDIDIKAN DASAR Vol 4.No.2 December 2019 Page 245-263

P-ISSN : 2614-7092, E-ISSN : 2621-966II

Available Cnline at Web : http://online-journal.unja.ac.id/index.php/gentala email : penyunting.jurnal.g-pgsd国unja.ac.id

kurangya kemampuan berpikir kritis ini disebabkan karena guru tidak menggunakan desain pembelajaran yang menarik dan kreatif sehingga kurang memiliki daya dukung dalam proses pembelajaran yang mengakibatkan siswa kurang bersemangat dalam mengikuti kegiatan pembelajaran, dan banyak siswa yang tidak menyelesaikan tugas latihan ataupun pekerjaan rumah yang diberikan guru. Kemampuan berpikir kritis yang kurang terlihat dari siswa yang tidak bisa menjawab pertanyaan yang diberikan guru, dan siswa hanya diam mendengarkan ceramah yang diberikan guru dan saat guru memberikan materi hanya ada beberapa orang siswa yang bertanya terhadap materi yang diberikan.

Faktor yang sangat berpengaruh dalam menghambat perkembangan kemampuan berpikir kritis siswa adalah kemampuan guru dalam menyampaikan materi serta desain pembelajaran yang terkesan membosankan sehingga ketertarikan siswa dalam mengikuti pembelajaran berkurang. Hal tersebut juga mengakibatkan hasil belajar siswa rendah.

Dari permasalahan di atas sebaiknya guru lebih menguasai materi dan untuk membangkitkan kemampuan berpikir kritis siswa guru sebaiknya menggunakan pola pembelajaran yang bervariasi dan kreatif seperti media pembelajaran, karena dengan menggunakan media dapat menarik perhatian siswa, dan merangsangsang rasa ingin tahu siswa terhadap pembelajaran dan meningkatkan kemampuan berpikir kritis serta membangkitkan semangat siswa dalam mengikuti kegiatan pembelajaran sehingga tujuan pembelajaran tercapai.

Masalah kurangnya berpikir kritis siswa pada kelas V ini tentu harus segera dilakukan sebuah tindakan supaya hasil belajar siswa pun dapat meningkat sesuai dengan yang diharapkan. Setelah melihat akar penyebab masalah di atas, peneliti mengambil tindakan dengan mencoba menggunakan media big book. Media big book merupakan salah satu media yang mampu meningkatkan kemampuan berpikir kritis siswa dengan bentuknya yang unik dan kreatif sehingga merangsang rasa ingin tahu siswa terhadap pembelajaran.

Big book adalah buku cerita yang berisi gambar-gambar dan sedikit penjelasan, buku ini memiliki karakteristik khusus seperti warna-warni dan ukuran yang besar, karakteristik big book yang warna-warni dan besar dapat menarik perhatian siswa saat pembelajaran dan menumbuhkan kemampuan berpikir kritis siswa dan memudahkan siswa dalam memahami pembelajaran.

Menurut USAID (2014:46) “media big book merupakan buku cerita yang berkarakteristik khusus yang berukuran besar, baik teks maupun gambarnya, memiliki 


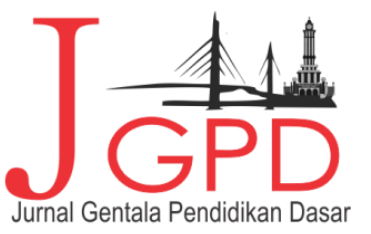

JURNAL GENTALA PENDIDIKAN DASAR Vol 4.No.2 December 2019 Page 245-263

P-ISSN : 2614-7092, E-ISSN : 2621-961I

Available Cnline at Web : http://anline-journal.unja.ac.id/index.php/gentala email : penyunting.jurnal.g-pgsd国unja.ac.id

gambar dalam setiap halaman, jumlah kata dan kalimat yang tidak terlalu banyak sehingga dapat dilakukan membaca bersama antara guru dan siswa".

Media ini dapat digunakan di kelas $\mathrm{V}$ karena media memiliki gambar yang menerik dan besar dan kalimat yang tidak terlalu banyak sehingga mampu membangkitkan karakteristik siswa kelas $\mathrm{V}$ yaitu mampu menyelidiki dan memiliki rasa ingin tahu yang tinggi. Media big book dapat membantu proses pembelajaran dalam merangsang cara berpikir kritis siswa dengan beberapa kelebihannya salah satunya yaitu tampilan yang menarik perhatian siswa sehingga siswa lebih fokus terhadap pembelajaran dengan fokusnya siswa terhadap pembelajaran diharapkan siswa lebih memahami pembelajaran sehingga siswa mampu menjawab pertanyaan serta aktif bertanya dan rasa ingin tahu siswa terhadap pembelajaran meningkat, media tersebut pun sangat mudah dibuat sendiri oleh guru.

Berdasarkan latar belakang masalah serta melihat kelebihan-kelebihan media big book, maka dalam penelitian ini diangkat judul "Meningkatkan kemampuan berpikir kritis siswa dengan menggunakan media big book pada siswa kelas V SD Negeri 13/I Rengas Condong.

\section{METODE PENELITIAN}

\section{Subjek Penelitian}

Adapun subjek penelitian ini adalah siswa kelas VE SD Negeri 13/I Rengas Condong yang berjumlah 22 siswa terdiri dari 13 orang siswa perempuan dan 9 orang siswa laki-laki. Alasan pemilihan kelas VE dikarenakan peneliti menemukan permasalahan berupa rendahnya kemampuan berpikir kritis siswa saat pembelajaran dan hasil belajar siswa yang rendah. Sedangkan objek penelitian ini adalah peningkatan kemampuan berpikir kritis pada kelas VE SD Negeri 13/I Rengas Condong dengan menggunakan media big book.

\section{Tempat dan Waktu Penelitian}

Penelitian ini direncanakan di SD Negeri 13/I Rengas Condong yang beralamat di Kelurahan Rengas Condong Kecamatan Muara Bulian Kabupaten Batang Hari, Provinsi jambi. Waktu penelitian ini direncanakan pada semester II tahun ajaran 2017/2018.

\section{Jenis Penelitian}

Penelitian ini termasuk penelitian tindakan kelas (classroom Action Reasearch). Dalam pelaksanaannya penelitian tindakan kelas ini terdiri dari beberapa tahapan : observasi 


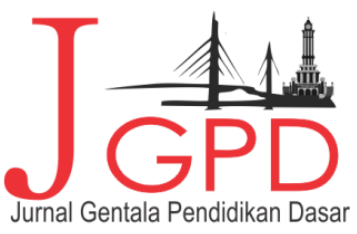

JURNAL GENTALA PENDIDIKAN DASAR Vol 4.No.2 December 2019 Page 245-263

P-ISSN : 2614-7092, E-ISSN : 2621-961I

Available Cnline at Web : http://anline-journal.unja.ac.id/index.php/gentala

email : penyunting.jurnal.g-pgsd国unja.ac.id

awal, perancanaan, pelaksanaan, observasi, dan refleksi. Penelitian ini akan dilakukan beberapa siklus. Siklus akan dihentikan

apabila siswa mengalami peningkatan kemampuan berpikir kritis, atau dalam kata lain sudah menunujukan bahwa big book dapat meningkatkan kemampuan berpikir kritis siswa.

\section{Prosedur Penelitian}

Dalam penelitian ini, peneliti menggunakan model alur penelitian tindakan kelas dari Kemmis dan Taggart, yaitu berbentuk spiral dari siklus yang satu ke siklus yang berikutnya. Setiap siklus meliputi observasi awal, perencanaan, pelaksanaan, observasi, refleksi. Langkah pada siklus berikutnya adalah perencanaan yang sudah direvisi, perencanaan, pelaksanaan, observasi, dan refleksi. Banyaknya siklus tidak dapat dipastikan, karena menyangkut terselesaikannya masalah dalam kelas yang diteliti, jika dalam satu atau dua siklus permasalahan yang ada sudah dapat diatasi maka penelitian dapat diakhiri, namun jika dalam satu atau dua siklus permasalahan belum dapat terselesaikan maka dilanjutkan ke siklus ketiga dan seterusnya.

Siklus kedua dan seterusnya dilaksanakan dengan merevisi faktor-faktor yang dianggap mampu memperbaiki hasil dari siklus sebelumnya. PTK dilaksanakan secara berulang dalam beberapa siklus di mana dalam setiap siklus tahap-tahap yang dilakukan adalah observasi awal, perencanaan, pelaksanaan, observasi, dan refleksi.

Untuk lebih rincinya prosedur penilain tindakan kelas ini dapat dijabarkan sebagai berikut:

\section{Observasi Awal}

a. Melakukan observasi ke sekolah dan wawancara dengan guru kelas V terkait dengan penelitian yang hendak dilakukan.

b. Melakukan observasi kegiatan belajar mengajar siswa di kelas.

c. Melakukan diskusi dengan guru kelas terkait permasalahan yang ditemukan dan apa yang menjadi solusi dari permasalahan itu.

d. Memilih solusi dari permasalahan yang ada, yaitu solusi yang dipilih adalah penggunaan media big book untuk mengatasi kurangnya kemampuan berpikir kritis.

\section{Perencanaan}

a. Menetapkan waktu penelitian dan kelas yang dijadikan subjek penelitian, yaitu kelas V SD Negeri 13/I Rengas Condong.

b. Membuat rencana pelaksanaan pembelajaran (RPP), 
c. Menyiapkan big book,

d. Penyusunan dan mempersiapkan instrumen alat evaluasi yang meliputi:

1. Lembar soal,

2. Kunci jawaban, dan

3. Pedoman penialaian.

\section{Pelaksanaan Tindakan}

Pelaksanaan tindakan dilakukan sesuai dengan jadwal pelajaran aktif kelas V SD Negeri 13/I Rengas Condong. Adapun tindakan yang akan dilakukan pada tiap siklus yaitu :

\subsubsection{Pendahuluan}

1. Mengucapkan salam

2. Menyapa siswa

3. Absen siswa

4. Guru menyampaikan mater yang diajarkan.

5. Guru menyampaikan tujuan pembelajaran

\subsubsection{Kegiatan Inti}

6. Guru membagi siswa menjadi berpasangan.

7. Guru memperlihatkan big book dan memperkenalkannya.

8. Guru meminta siswa membaca judul atau materi pelajaran yang terletak disampul big book.

9. Guru bertanya jawab tentang materi yang akan di pelajari

10. Guru membuka halaman big book dan memperlihatkan gambarnya.

11. Guru bertanya kepada siswa apa yang mereka ketahui tentang gambar tersebut.

12. Guru memberikan penjelasan tentang gambar.

13. Sebelum membuka halaman selanjutnya guru bertanya kepada siswa untuk menduga gambar selanjutnya.

14. Setelah seluruh halaman selesai diperlihatkan dan dijelaskan guru memberi pertanyaan berkaitan dengan materi.

15. Selanjutnya guru memberi tugas, setiap pasangan diberi tugas satu untuk menyebutkan gambar dan satu menjelaskan gambar.

16. Guru memberikan LKS kepada masing-masing siswa.

17. Siswa mengerjakan LKS yang diberikan guru

18. Siswa menarik kesimpulan dari materi big book. 


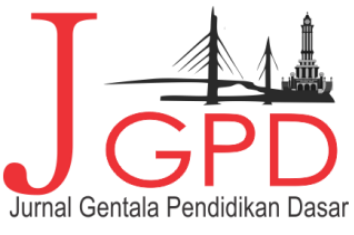

JURNAL GENTALA PENDIDIKAN DASAR Vol 4.No.2 December 2019 Page 245-263

P-ISSN : 2614-7092, E-ISSN : 2621-9611

Available Dnline at Web : http://online-journal.unja.ac.id/index.php/gentala email : penyunting.jurnal.g-pgsd国unja.ac.id

19. Guru memberi penguatan

20. Guru memberi umpan balik

\subsubsection{Penutup}

21. Guru memberikan hadiah kepada pasangan yang berhasil menyelesaikan tugas.

22. Guru dan siswa membuat kesimpulan bersama-sama.

23. Guru memberikan pesan dan nasehat kepada siswa.

24. Berdoa

\section{Observasi}

Observasi dilakukan selama proses pembelajaran dengan menggunakan lembar observasi yang telah disiapkan dan mencatat kejadian-kejadian yang tidak terdapat dalam lembar observasi dengan membuat lembar catatan lapangan. Hal-hal yang diamati selama proses pembelajaran adalah kegiatan pembelajaran. Observasi dalam penelitian ini difokuskan pada kemampuan berpikir kritis siswa yang dilakukan selama proses pembelajaran berlangsung.

Lembar observasi digunakan untuk menjaring data dalam proses belajar mengajar. Melalui pedoman observasi yang ada pada lembar observasi, peneliti akan lebih mudah mengamati aktivitas siswa. Aktivitas yang dijaring dalam lembar observasi terhadap bahan pembelajaran. Observasi yang akan dilakukan meliputi beberapa aspek, sesuai dengan karakteristik kemampuan berpikir kritis pada penelitian ini menurut para ahli, yaitu :

1. Mengenal masalah

2. Menemukan cara-cara yang dapat dipakai untuk menangani masalah-masalah itu.

3. Mengumpulkan dan menyusun informasi yang diperlukan.

4. Mengenal asumsi-asumsi dan nilai-nilai yang tidak dinyatakan.

5. Memahami dan menggunakan bahasa yang tepat, jelas, dan khas.

6. Menganalisis data

7. Menilai fakta dan mengevaluasi pernyataan-pernyataan.

8. Mengenal adanya hubungan yang logis antara masalah-masalah.

9. Menarik kesimpulan-kesimpulan dan kesamaan-kesamaan yang diperlukan.

10. Menguji kesamaan-kesamaan dan kesimplan-kesimpulan yang seseorang ambil.

11. Menyusun kembali pola-pola keyakinan seseorang berdasarkan pengalaman yang lebih luas. 


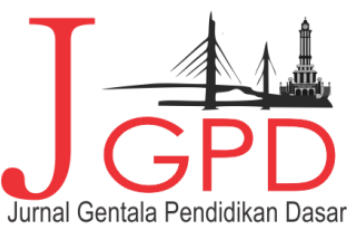

JURNAL GENTALA PENDIDIKAN DASAR Vol 4.No.2 December 2019 Page 245-263

P-ISSN : 2614-7092, E-ISSN : 2621-961I

Available Online at Web : http://online-journal.unja.ac.id/index.php/gentala

email : penyunting.jurnal.g-pgsd国unja.ac.id

12. Membuat penilaian yang tepat tentang hal-hal dan kualitas-kualitas tertentu dalam

kehdupan sehari-hari.

Dalam penelitian ini peneliti menggunakan instrument berupa lembar observasi yang memiliki tingkatan penilaian. Selain lembar observasi siswa, penelitian ini juga menggunakan lembar observasi proses pembelajaran yang berisi langkah-langkah pembelajaran yang dilakukan oleh peneliti.

\section{Refleksi}

Pada tahap refleksi, peneliti bersama guru melakukan evaluasi dari pelaksanaan tindakan pada siklus 1 yang digunakan sebagai bahan pertimbangan perencanaan pembelajaran pada siklus selanjutnya. Setelah data selesai dianalisis, dengan menggunakan indikator keberhasilan yang telah ditetapkan selanjutnya ditarik kesimpulan tentang keberhasilan atau kegagalan tindakan apabila presentase keberhasilan siswa mencapai $70 \%$, maka penelitian tidak perlu dilanjutkan kesiklus berikutnya, tetapi jika presentase keberhasilan siswa kurang dari 70\%, maka penelitian harus dilanjutkan pada siklus berikutnya.

\section{Teknik Pengumpulan Data}

Teknik pengumpulan data merupakan cara kerja untuk mendapatkan data dari obyek tertentu. Data yang didapatkan dalam penelitian dapat berupa data yang sifatnya kuantitatif dan kualitatif. Data adalah hasil pencatatan peneliti baik yang berupa fakta maupun angka (Arikunto, 2010:193).

Teknik-teknik pengumpulan data yang dilakukan pada penelitian ini adalah :

\section{Observasi}

Metode observasi adalah cara pengumpulan data dengan jalan mengadakan pengamatan dan pencatatan secara sistematis fenomena-fenomena yang diselidiki. Metode ini dilakukan untuk melihat peningkatan kemampuan berpikir kritis siswa. Adapun alat pengumpul data pada teknik observasi ini adalah berupa lembar observasi mengenai aktivitas berpikir kritis siswa pada kegiatan pembelajaran di kelas.

Kegiatan yang diamati adalah proses pembelajaran menggunakan big book yang digunakan guru, serta mengamati kegiatan siswa dan melihat kemampuan berpikir kritisnya.

\section{Lembar Observasi Kegiatan Guru Menggunakan Big Book}

Nama Sekolah 


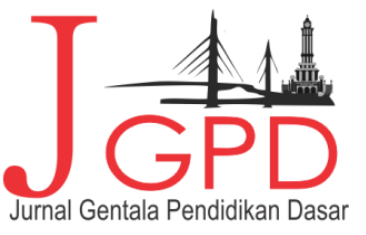

JURNAL geNTALA PENDIDIKAN DASAR Vol 4.No.2 December 2019 Page 245-263

P-ISSN : 2614-7092, E-ISSN : 2621-9611

Available Dnline at Web : http://online-journal.unja.ac.id/index.php/gentala email : penyunting.jurnal.g-pgsd国unja.ac.id

Nama Guru

Mata Pelajaran

Kelas

Hari/Tanggal

Petunjuk Pengisisan:

1. Pengamatan ditunjukan kepada guru (peneliti)

2. Memberikan tanda ceklis $(\sqrt{ })$ pada kolom skor yang sesuai dengan pengamatan pada aspek yang diteliti.

Tabel 3.1 Lembar Observasi Guru

\begin{tabular}{|c|c|c|c|c|c|}
\hline \multirow[t]{2}{*}{ No } & \multirow{2}{*}{$\begin{array}{c}\text { Sintak } \\
\text { pembelajaran }\end{array}$} & \multirow{2}{*}{ Kegiatan Guru } & \multirow{2}{*}{ No. Item } & \multicolumn{2}{|c|}{ Keterlaksanaan } \\
\hline & & & & $\mathrm{Ya}$ & Tidak \\
\hline \multirow[t]{5}{*}{1.} & \multirow{5}{*}{ Pendahuluan } & Mengucapkan salam & 1 & & \\
\hline & & Menyapa siswa & 2 & & \\
\hline & & Absen siswa & 3 & & \\
\hline & & Guru menyampaikan materi & 4 & & \\
\hline & & $\begin{array}{l}\text { Guru menyampaikan tujuan } \\
\text { pembelajaran }\end{array}$ & 5 & & \\
\hline \multirow[t]{13}{*}{2} & Kegiatan & $\begin{array}{l}\begin{array}{l}\text { Guru membagi } \\
\text { berpasangan }\end{array} \\
\end{array}$ & 6 & & \\
\hline & & $\begin{array}{l}\text { Guru memperlihatkan big book dan } \\
\text { memperkenalkannya. }\end{array}$ & 7 & & \\
\hline & & $\begin{array}{l}\text { Guru meminta siswa membaca materi } \\
\text { pelajaran yang terletak pada sampul } \\
\text { big book }\end{array}$ & 8 & & \\
\hline & & $\begin{array}{l}\text { Guru bertanya jawab tentang materi } \\
\text { yang akan dipelajari }\end{array}$ & 9 & & \\
\hline & & $\begin{array}{l}\text { Guru membuka halaman big book dan } \\
\text { memperlihatkan gambarnya }\end{array}$ & 10 & & \\
\hline & & $\begin{array}{l}\text { Guru bertanya kepada sisiwa apa yang } \\
\text { mereka ketahui tentang gambar } \\
\text { tersebut }\end{array}$ & 11 & & \\
\hline & & $\begin{array}{l}\text { Guru memberikan penjelasan tentang } \\
\text { gambar }\end{array}$ & 12 & & \\
\hline & & $\begin{array}{l}\text { Sebelum membuka halaman } \\
\text { selanjutnya guru meminta siswa untuk } \\
\text { menduga gambar selanjutnya }\end{array}$ & 13 & & \\
\hline & & $\begin{array}{l}\text { Setelah seluruh halaman selesai } \\
\text { diperlihatkan dan dijelaskan guru } \\
\text { memeberi pertanyaan tentang materi. }\end{array}$ & 14 & & \\
\hline & & $\begin{array}{l}\text { Selanjutnya guru memberi tugas, } \\
\text { setiap pasangan diberi tugas satu } \\
\text { menyebutkan satu menjelaskan. }\end{array}$ & 15 & & \\
\hline & & $\begin{array}{l}\text { Guru memberi LKS kepada masing- } \\
\text { masing siswa }\end{array}$ & 16 & & \\
\hline & & $\begin{array}{lll}\begin{array}{l}\text { Siswa mengerjakan } \\
\text { diberikan guru }\end{array} & \text { LKS } & \text { yang } \\
\end{array}$ & 17 & & \\
\hline & & Siswa menarik kesimpulan dari materi & 18 & & \\
\hline
\end{tabular}

Copyright (c) 2019 Issaura Sherly Pamela, Suci Hayati, Rila Suci Insani Attribution-NonCommercial-ShareAlike 4.0 International License 
Available Dnline at Web : http://online-journal.unja.ac.id/index.php/gentala email : penyunting.jurnal.g-pgsd国unja.ac.id

\begin{tabular}{|l|l|c|c|c|}
\hline & big book & & \\
\hline & Guru memberi penguatan & 19 & & \\
\hline & Guru memberi umpan balik & 20 & & \\
\hline & $\begin{array}{l}\text { Guru memberikan hadiah kepada } \\
\text { pasangan yang berhasil menyelesaikan } \\
\text { tugas }\end{array}$ & 21 & & \\
\hline $\begin{array}{l}\text { Guru dan siswa membuat kesimpulan } \\
\text { bersama-sama }\end{array}$ & 22 & & \\
\hline & $\begin{array}{l}\text { Guru memberikan pesan dan nasehat } \\
\text { kepada siswa. }\end{array}$ & 23 & & \\
\hline Berdoa & 24 & & \\
\hline
\end{tabular}

\section{Presentasinya :}

Tabel 3.2 Skala Peniliain observasi Guru

\begin{tabular}{|c|c|}
\hline Presentase Rata-rata & Kategori \\
\hline $85 \%-100 \%$ & Sangat Terlaksana \\
\hline $51 \%-75 \%$ & Terlaksana \\
\hline $26 \%-50 \%$ & Cukup terlaksana \\
\hline $0-25 \%$ & Sangat kurang Teralaksana \\
\hline
\end{tabular}

(Aries dan Haryanto 2012:95)

Pengamat

\section{Lembar Observasi Kemampuan Berpikir Kritis Siswa}

Nama siswa

Materi Pembelajaran

Kelas/semester

Hari/Tanggal

Petunjuk :

1. Pengamatan ditunjukan kepada guru siswa

2. Memberikan tanda ceklis $(\sqrt{ }$ ) pada kolom skor yang sesuai dengan pengamatan pada aspek yang diteliti.

Tabel 3.3 Lembar Berpikir Kritis Siswa

\begin{tabular}{|c|l|c|c|}
\hline No & \multicolumn{1}{|c|}{ Ciri-ciri Berpikir Kritis } & Ya & Tidak \\
\hline 1. & Mengenal masalah & & \\
\hline 2. & $\begin{array}{l}\text { Menemukan cara-cara yang dapat dipakai untuk mennggapi } \\
\text { masalah-masalah itu. }\end{array}$ & & \\
\hline 3. & Mengumpulkan dan menyusun informasi yang diperlukan & & \\
\hline 4. & Mengenal asumsi-asumsi dan nilai-nilai yang tidak dinyatakan & & \\
\hline
\end{tabular}




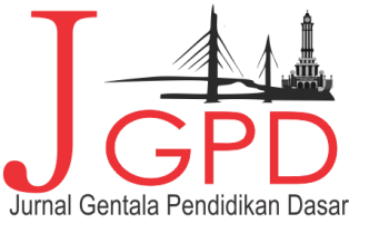

JURNAL geNTALA PENDIDIKAN DASAR Vol 4.No.2 December 2019 Page 245-263

P-ISSN : 2614-7092, E-ISSN : 2621-9611

Available Dnline at Web : http://online-journal.unja.ac.id/index.php/gentala email : penyunting.jurnal.g-pgsd国unja.ac.id

\begin{tabular}{|c|l|l|l|}
\hline 5. & Memahami dan menggunakan bahasa yang teppat, jelas, dan khas. & & \\
\hline 6. & Menganalisis data & & \\
\hline 7. & Menilai fakta dan mengevaluasi pernyatan-pernyataan & & \\
\hline 8. & Mengenal adanya hubungan yang logis antara masalah-masalah & & \\
\hline 9. & Menarik kesimpulan dan kesamaan-kesamaan yang diperlukan & & \\
\hline 10. & $\begin{array}{l}\text { Menguji kesamaan kesamaan dan kesimpulan-kesimpulan yang } \\
\text { seseorang ambil }\end{array}$ & $\begin{array}{l}\text { Menyusun kembali pola-pola keyakinan seseorang berdasarkan } \\
\text { pengalaman yang lebih luas }\end{array}$ & $\begin{array}{l}\text { Membuat penilaian yang tepat tentang hal-hal dan kualitas-kualitas } \\
\text { tertentu dalam kehidupan sehari-hari }\end{array}$ \\
\hline 11. & & \\
\hline Jumlah & & \\
\hline
\end{tabular}

Presentase $=\frac{\text { jumlah skor }}{\text { Skor Maksimal }} \times 100 \%$

Tabel 3.4 Taraf Keberhasilan Tindakan

\begin{tabular}{|c|c|l|}
\hline No & Nilai & \multicolumn{1}{|c|}{ Taraf Keberhasilan } \\
\hline 1 & $85-100$ & A (Sangat Kritis) \\
\hline 2 & $70-84$ & B (Kritis) \\
\hline 3 & $55-69$ & C (Cukup Kritis) \\
\hline 4 & $40-54$ & D (Kurang Kritis) \\
\hline 5 & $\leq 39$ & E(Sangat Kurang Kritis) \\
\hline
\end{tabular}

Sumber:Aries dan Hariyono (2012:95)

Tes

Evaluasi hasil belajar dilakukan melalui pengerjaan soal-soal ulangan yang berkaitan dengan pokok bahasan materi yang telah diajarkan. Dari hasil ulangan tersebut kemudian dievaluasi untuk digunakan sebagai ukuran keberhasilan siswa pada pokok bahasan yang telah didiskusikan. Pengumpulan data dengan teknik tes ini dilakukan untuk melihat peningkatan hasil belajar siswa. Sementara alat pengumpul data pada teknik tes adalah berupa lembar soal tes esai.

\section{Teknik Analisis Data}

Pengumpulan data dalam penelitian ini dilakukan dengan beberapa cara yakni dengan memberikan tes dan lembar observasi. Teknik analisis data dengan perhitungan data tersebut adalah sebagai berikut :

\section{Teknik Analisis Data Kualitatif}

Pada penelitian tindakan kelas ini, digunakkan analisis deskripsi kualitatif, yaitu suatu metode penelitian yang bersifat menggambarkan kenyataan atau fakta yang disesuaikan 


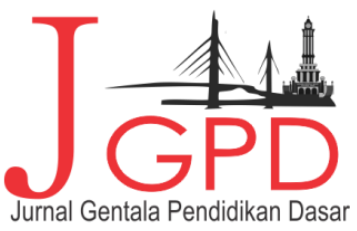

JURNAL GENTALA PENDIDIKAN DASAR Vol 4.No.2 December 2019 Page 245-263

P-ISSN : 2614-7092, E-ISSN : 2621-9611

Available Dnline at Web : http://online-journal.unja.ac.id/index.php/gentala email : penyunting.jurnal.g-pgsd国unja.ac.id

dengan fakta yang diperoleh dari hasil lembar observasi kemampuan berpikir kritis siswa, dan aktivitas guru selama dalam proses pembelajaran.

\section{Teknik Analisis Data Kuantitatif}

1) Teknik analisis hasil lembar observasi kemampuan berpikir kritis siswa dianalisis dengan menggunakan rumus sebagi berikut:
a. memberikan tanda cheklis pada masing-masing aspek
b. menjumlahkan skor dari cheklis masing-masing aspek
c. menghitung presentase dengan rumus :

Presentase $=\frac{\text { jumlah skor }}{\text { Skor Maksimal }} \times 100 \%$

Skor yang ditentukan kemudian disesuaikan dengan kriteria yang telah ditentukan. Menurut Aries dan Hariyono (2012:95) taraf keberhasilan tindakan yang telah dihitung dengan kriteria presentase seperti berikut:

Tabel 3.5 Taraf Keberhasilan Tindakan

\begin{tabular}{|c|c|l|}
\hline No & Nilai & \multicolumn{1}{|c|}{ Taraf Keberhasilan } \\
\hline 1 & $85-100$ & A (Sangat Kritis) \\
\hline 2 & $70-84$ & B (Kritis) \\
\hline 3 & $55-69$ & C (Cukup Kritis) \\
\hline 4 & $40-54$ & D (Kurang Kritis) \\
\hline 5 & $\leq 39$ & E(Sangat Kurang Kritis) \\
\hline
\end{tabular}

Sumber:Aries dan Hariyono (2012:95)

2) Analisis Hasil Tes Kemampuan Berpikir Kritis Siswa

a. Ketuntasan individu dan ketuntasan belajar secara klasikal apabila telah mencapai nilai minimal 2,66 dengan predikat B (Baik) dipilih karena sesuai dengan kriteria ketuntasan minimal yang telah tertera pada rentang nilai kompetensi pengetahuan dan KKM kelas V E SD Negeri 13/1 Rengas Condong. Data ini diolah dengan rumus:

$$
\text { Nilai }=\frac{\text { Skor } \text { yang diperoleh }}{\text { Total Skor Maksimum }} \times 100 \%
$$

b. Rentang nilai Kompetensi Pengetahuan, yaitu:

Tabel 3.6 Rentang Nilai Kompetensi Pengetahuan

\begin{tabular}{|l|c|c|}
\hline No & Nilai & Predikat \\
\hline
\end{tabular}

Copyright (c) 2019 Issaura Sherly Pamela, Suci Hayati, Rila Suci Insani Attribution-NonCommercial-ShareAlike 4.0 International License 


\begin{tabular}{|c|c|c|}
\hline 1 & $3,66<$ Nilai $\leq 4,00$ & A \\
\hline 2 & $3,33<$ Nilai $\leq 3,66$ & A- \\
\hline 3 & $3,00<$ Nilai $\leq 3,33$ & B+ \\
\hline 4 & $2,66<$ Nilai $\leq 3,00$ & B \\
\hline 5 & $2,33<$ Nilai $\leq 2,66$ & B- \\
\hline 6 & $2,00<$ Nilai $\leq 2,33$ & C+ \\
\hline 7 & $1,66<$ Nilai $\leq 2,00$ & C \\
\hline 8 & $1,33<$ Nilai $\leq 1,66$ & C- \\
\hline 9 & $1,00<$ Nilai $\leq 1,33$ & D+ \\
\hline 10 & $0,00<$ Nilai $\leq 1,00$ & D \\
\hline
\end{tabular}

Sumber:Kurniasih \& Berlin (2014:100)

\section{Kriteria Keberhasilan}

Penelitian ini akan dikatakan berhasil apabila sudah mengalami peningkatan kemampuan berpikir kritis siswa saat guru menggunakan media big book dalam proses pembelajaran. Adapun rincian keberhasilan adalah : adanya peningkatan berpikir kritis siswa kelas V SD Negeri 13/I Rengas condong setelah menggunakan media big book.

Kriteria ketuntasan individu adalah minimal berkualitas 'Baik'. Penelitian ini dianggap berhasil apabila jumlah siswa tuntas mencapai $70 \%$ dari jumlah seluruh siswa.

\section{Hasil Penelitian dan Pembahasan}

\section{Hasil Penelitian}

Berikut ini merupakan hasil observasi kemampuan berpikir kritis dari masing-masing siswa dari pertemuan I sampai pertemuan II pada siklus I, yaitu:

Tabel 4.5 Hasil Observasi Kemampuan Berpikir Kritis Siswa Siklus I

\begin{tabular}{|l|l|c|c|c|c|c|}
\hline No & Nama Siswa & Pertemuan I & Pertemuan II & Jumlah & Rata-rata & Predikat \\
\hline 1. & AKP & 75 & 83 & 158 & 79 & B \\
\hline 2. & ADR & 50 & 58 & 108 & 54 & D \\
\hline 3. & AWZ & 58 & 58 & 116 & 58 & C \\
\hline 4. & AS & 50 & 66 & 116 & 58 & C \\
\hline 5. & DA & 83 & 83 & 166 & 83 & B \\
\hline 6. & DDS & 58 & 66 & 124 & 62 & C \\
\hline 7. & FAG & 91 & 91 & 182 & 91 & A \\
\hline 8. & FK & 41 & 58 & 99 & 49 & D \\
\hline 9. & FA & 33 & 50 & 83 & 41 & D \\
\hline 10. & IAN & 41 & 41 & 82 & 41 & D \\
\hline 11. & MVA & 83 & 75 & 158 & 79 & B \\
\hline 12. & MIAS & 41 & 50 & 91 & 45 & D \\
\hline 13. & MIIS & 41 & 41 & 82 & 41 & D \\
\hline 14. & NSA & 58 & 75 & 133 & 66 & C \\
\hline 15. & NWA & 25 & 41 & 66 & 33 & E \\
\hline 16. & RS & 66 & 83 & 149 & 74 & B \\
\hline 17. & RDP & 75 & 75 & 150 & 75 & B \\
\hline
\end{tabular}




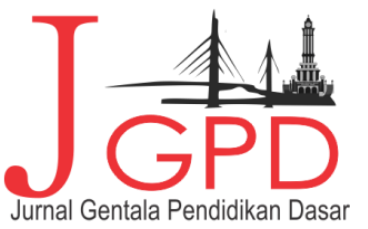

JURNAL GENTALA PENDIDIKAN DASAR Vol 4.No.2 December 2019 Page 245-263

P-ISSN : 2614-7092, E-ISSN : 2621-9611

Available Dnline at Web : http://online-journal.unja.ac.id/index.php/gentala email : penyunting.jurnal.g-pgsd国unja.ac.id

\begin{tabular}{|c|c|c|c|c|c|c|}
\hline 18. & RDPA & 50 & 66 & 116 & 58 & $\mathrm{C}$ \\
\hline 19. & $\mathrm{RA}$ & 58 & 83 & 141 & 70 & B \\
\hline 20. & SAP & 75 & 75 & 150 & 75 & $\mathrm{~B}$ \\
\hline 21. & $S$ & 41 & 58 & 99 & 49 & $\mathrm{C}$ \\
\hline 22 & SW & 66 & 75 & 141 & 70 & B \\
\hline \multicolumn{2}{|c|}{ Jumlah } & 1259 & 1451 & 2710 & 1351 & $A=1$ \\
\hline \multicolumn{2}{|c|}{ Rata-rata } & 57.2 & 65,9 & 123,18 & $61,4 \%$ & $\begin{array}{l}B=8 \\
C=6 \\
D=6 \\
E=1\end{array}$ \\
\hline \multicolumn{2}{|c|}{$\begin{array}{l}\text { Presentase Berpikir } \\
\text { Kritis Siswa Secara } \\
\text { Klasikal. }\end{array}$} & \multicolumn{5}{|c|}{$61,4 \%$} \\
\hline
\end{tabular}

Hasil observasi kemampuan berpikir kritis siswa siklus I yang telihat pada tabel 4.5 di mana pada pertemuan I rata-rata kemampuan berpikir kritis siswa 57,2 dan terjadi peningkatan dipertemuan II dimana rata-rata kemampuan berpikir kritis siswa 65,9 dengan presentase kemampuan berpikir kritis siswa pada sikus I secara klasikal adalah $61,4 \%$ di mana pada presentase tersebut dikategorikan kurang dan masih perlu dilakukan peningkatan pada siklus selanjutnya.

\section{Refleksi Siklus I}

Pada siklus I ini pembelajaran belum begitu maksimal ternyata hasil yang diperolah pada siklus I belum sesuai dengan yang diharapkan atau belum mencapai kriteria. Dikarenakan masih banyak kekurangan yang di alami baik guru maupun siswa itu sendiri. Adapun kelemahan-kelemahan pada siklus I tersebut ialah:

1) Guru tidak membuat tata tertib pada saat proses pembelajaran.

2) Siswa masih kaku dalam proses pembelajaran.

3) Siswa Masih malu dalam mengemukakan pendapat dan bertanya.

4) Pada kegiatan akhir guru kurang maksimal dalam melakukan kesimpulan bersama siswa sehingga sedikit sekali siswa yang menyimpulkan pembelajaran.

5) Sebagian besar siswa masih malu untuk menyajikan hasil diskusinya.

Untuk mengatasi kelemahannya yang terjadi pada siklus I guru dan peneliti merencanakan untuk memperbaiki pada siklus II yag telah dirancang secara bersama, yaitu:

1) Mengarahkan siswa agar pembelajaran lebih efektif.

2) Mengarahkan siswa yang kaku agar terlibat aktif saat mengikuti proses pembelajaran.

3) Memberikan motivasi dan pengarahan kepada siswa agar lebih percaya diri saat berpendapat dan menyajikan hasil di depan kelas.

4) Memperbaiki alokasi waktu agar pembelajaran dapat berjalan sesuai yang diharapkan. 


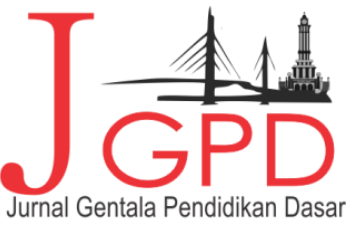

JURNAL GENTALA PENDIDIKAN DASAR Vol 4.No.2 December 2019 Page 245-263 P-ISSN : 2614-7092, E-ISSN : 2621-966II

Available Online at Web : http://online-journal.unja.ac.id/index.php/gentala email : penyunting.jurnal.g-pgsd国unja.ac.id

Berikut ini merupakan hasil observasi kemampuan berpikir kritis dari masing-masing siswa dari pertemuan I sampai pertemuan II pada siklus II, yaitu :

Tabel 4.9. Hasil Observasi Kemampuan Berpikir Kritis Siswa Siklus II

\begin{tabular}{|l|l|c|c|c|c|c|}
\hline No & Nama Siswa & Pertemuan I & Pertemuan II & Jumlah & Rata-rata & Predikat \\
\hline 1. & AKP & 83 & 91 & 174 & 87 & A \\
\hline 2. & ADR & 75 & 83 & 158 & 79 & B \\
\hline 3. & AWZ & 75 & 83 & 158 & 79 & B \\
\hline 4. & AS & 75 & 83 & 158 & 79 & B \\
\hline 5. & DA & 75 & 91 & 166 & 83 & B \\
\hline 6. & DDS & 83 & 91 & 174 & 87 & A \\
\hline 7. & FAG & 91 & 91 & 182 & 91 & A \\
\hline 8. & FK & 75 & 75 & 150 & 75 & B \\
\hline 9. & FA & 75 & 75 & 150 & 75 & B \\
\hline 10. & JAN & 50 & 66 & 116 & 58 & C \\
\hline 11. & MVA & 83 & 91 & 174 & 87 & A \\
\hline 12. & MIAS & 50 & 58 & 108 & 54 & D \\
\hline 13. & MIIS & 58 & 66 & 124 & 62 & C \\
\hline 14. & NSA & 75 & 83 & 158 & 79 & B \\
\hline 15. & NWA & 41 & 66 & 107 & 53 & D \\
\hline 16. & RS & 91 & 83 & 174 & 87 & A \\
\hline 17. & RDP & 91 & 83 & 174 & 87 & A \\
\hline 18. & RDPA & 66 & 91 & 157 & 78 & B \\
\hline 19. & RA & 83 & 83 & 166 & 83 & A \\
\hline 20. & SAP & 75 & 83 & 158 & 79 & B \\
\hline 21. & S & 75 & 75 & 150 & 75 & B \\
\hline 22 & SW & 83 & 91 & 174 & 87 & A \\
\hline Jumlah & 1652 & 1758 & 3410 & 1704 & A=8 \\
\hline Rata-rata & 75 & 79 & 155 & $77 \%$ & B=10 \\
\multicolumn{2}{|l|}{} & & & & & C=2 \\
\hline $\begin{array}{l}\text { Presentase Berpikir } \\
\text { Kritis Siswa Secara } \\
\text { Klasikal. }\end{array}$ & & & & & \\
\hline
\end{tabular}

Hasil observasi kemampuan berpikir kritis siswa siklus II yang terlihat pada tabel dimana pada pertemuan I rata-rata kemampuan berpikir kritis siswa 75 dan terjadi peningkatan dipertemuan II dimana rata-rata kemampuan berpikir kritis siswa 79 dengan presentase kemampuan berpikir kritis siswa pada siklus II secara klasikal adalah $77 \%$. Dimana pada presentase tersebut dikategorikan baik dan telah ditentukan. Berdasarkan dengan meningkatnya kemampuan berpikir kritis siswa pada siklus II ini maka penelitian dihentikan pada siklus II ini.

\section{Refleksi Siklus II}

Berdasarkan hasil observasi pada silus II kemampuan berpikir kritis siswa meningkat dari siklus I. Hal ini dapat dilihat dari hasil analisis yang dapat disimpulkan bahwa 


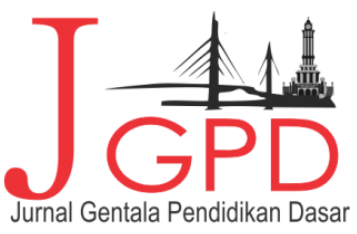

JURNAL GENTALA PENDIDIKAN DASAR Vol 4.No.2 December 2019 Page 245-263

P-ISSN : 2614-7092, E-ISSN : 2621-961I

Available Online at Web : http://online-journal.unja.ac.id/index.php/gentala email : penyunting.jurnal.g-pgsd国unja.ac.id

penggunaan media big book dapat meningkatkan kemampuan berpikir kritis siswa kelas VE SDN 13/I Rengas Condong. Meskipun masih terdapat beberapa siswa yang masih tergolong kategori kurang. Namun guru harus tetap memberi bimbingan lebih kepada siswa dalam proses pembelajaran sesuai dengan kebutuhan siswa itu sendiri. Berdasarkan hasil pengamatan siklus II yang telah meningkat, maka tindakan dapat dihentikan karena kemampuan berpikir kritis siswa kelas VE SDN 13/I Rengas Condong telah meningkat menjadi lebih baik. Hal ini dapat dibuktikan dengan terpenuhi nya 12 ciri-ciri berpikir kritis. 12 ciri-ciri berpikir kritis tersebut telah dianalisis dimasing-masing pertemuan setiap siklus dan dihitung secara klasikal ternyata pada siklus II telah memenuhi kriteria keberhasilan.

\section{Pembahasan}

Berdasarkan penelitian yang telah dilakukan dari siklus I sampai siklus II bahwa telah terjadi peningkatan kemampuan berpikir kritis siswa dengan tindakan yang dipilih salah satu media yaitu big book di kelas VE SDN 13/I Rengas Condong. Desain tindakan yang dilakukan oleh peneliti meliputi empat tahapan yaitu: perencanaan, pelaksanaan, observasi dan refleksi.

Pada tahap perencanaan setiap siklusnya guru merencanakan serta menyiapkan perangkat pembelajaran yang akan digunakan yaitu: RPP, bahan ajar, media, materi yang akan dipelajari, lembar observasi kemampuan berpikir kritis siswa dan aktivitas guru selama proses pembelajaran, LKPD dan soal evaluasi akhir siklus I dan siklus II, sedangkan pada tahap pelaksanaan setiap siklusnya dilaksanakan sebanyak 2 kali pertemuan. Pertemuan I dan II digunakan untuk melaksanakan proses pembelajaran dengan menggunakan media big book untuk meningkatkan kemampuan berpikir kritis siswa. Sementara untuk evaluasi akhir dilaksanakan pada setiap akhir siklus pertemuan ke II.

Pada tahap observasi, guru mengamati perubahan berpikir kritis siswa selama dalam proses pembelajaran dan memberikan tanda cheklist sesuai dengan ciri-ciri yang telah ada. Pada tahap ini guru dapat mengetahui presentase kemampuan berpikir kritis dari masingmasing siswa, sehingga guru juga dapat menyimpulkan apakah terdapat peningkatan atau tidak pada tiap siklusnya dengan mengacu pada kriteria keberhasilan yang telah ditentukan. Pada siklus I nilai rata-rata hasil evaluasi akhir siklus I secara klasikal yaitu 2,53 dengan predikat (B-) atau presentase keberhasilan kelas dari hasil tes siswa yang tuntas yaitu 45,5\% sedangkan hasil observasi pada siklus I presentase keberhasilan kelas yaitu 61,4\% dengan 


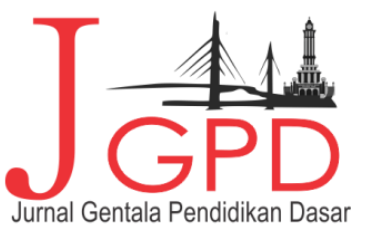

JURNAL GENTALA PENDIDIKAN DASAR Vol 4.No.2 December 2019 Page 245-263

P-ISSN : 2614-7092, E-ISSN : 2621-961I

Available Online at Web : http://online-journal.unja.ac.id/index.php/gentala email : penyunting.jurnal.g-pgsd国unja.ac.id

predikat (C). Pada siklus I ini presentase keberhasilan belum mencapai pada kriteria keberhasilan yang telah ditetapkan oleh peneliti yaitu $70 \%$ maka penelitian berlanjut pada siklus II.

Tahapan akhir adalah refleksi yaitu dengan menganalisis dari hasil observasi dan mengidentifikasi tindakan yang harus dipertahankan, ditingkatkan maupun yang harus diperbaiki dan bahkan yang ditiadakan. Hasil refleksi pada siklus I digunakan untuk memperbaiki maupun menyempurnakan tindakan yang akan dilakukan pada siklus berikutnya. Berdasarkan refleksi pada siklus I ada beberapa hal yang ditemukan baik pada siswa maupun guru. Kegiatan yang perlu dipertahankan pada siklus I yang dilakukan sebanyak 2 kali pertemuan selama proses pembelajaran ialah melakukan kegiatan awal dengan mengajak memotivasi siswa dan melakukan refleksi diakhir pembelajaran. Sedangkan kegiatan guru yang harus diperbaiki yaitu mengarahkan siswa agar pembelajaran lebih efektif, mengarahkan siswa yang kaku agar terlibat aktif saat mengikuti proses pembelajaran, memberikan motivasi dan pengarahan kepada siswa agar lebih percaya diri saat berpendapat dan menyajikan hasil di depan kelas, memperbaiki alokasi waktu agar pembelajaran dapat berjalan sesuai yang diharapkan.

\section{KESIMPULAN DAN IMPLIKASI}

\section{Kesimpulan}

Berdasarkan hasil penelitian dan pembahasan, maka dapat disimpulkan bahwa penggunaan big book dapat meningkatkan kemampuan berpikir kritis siswa pada mata pelajaran IPS kelas VE SDN 13/I Rengas Condong. Big book yang digunakan dalam pembelajaran berbeda dengan bentuk buku biasa seperti yang digunakan sehari-hari siswa. Big book memiliki ukuran yang lebih besar, gambar yang lebih jelas dan warna-warna yang menarik. Hal itu membuat perhatian siswa lebih tertuju pada pembelajaran serta siswa menjadi lebih semangat dalam bertanya dan menjawab pertanyaan karena siswa ingin mengetahui gambar-gambar yang terdapat dalam big book tersebut. Peningkatan presentase kemampuan berpikir kritis siswa pada mata pelajaran IPS rata-rata yaitu, pada saat pre test rata-rata nilai siswa 2,33 dengan presentase $27 \%$, pada siklus I nilai rata-rata siswa meningkat sebanyak 2,53 dengan peresentase 45,5\%, Dari hasil penelitian tersebut, maka terbukti dengan menggunakan big book dapat meningkatkan kemampuan berpikir kritis siswa pada mata pelajaran IPS kelas VE SDN 13/I Rengas Condong. 


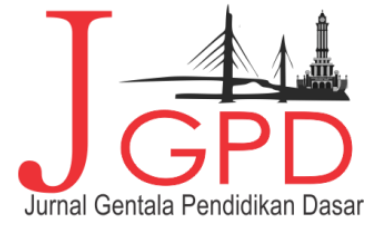

\section{Implikasi}

Implikasi dari penelitian ini ialah kegunaan big book sesuai dengan masalah yang berkaitan dengan kemampuan berpikir kritis siswa pada pembelajaran IPS. Hal tersebut dikarenakan kelebihan big book yang dapat merangsang siswa untuk aktif bertanya, mengmukakan pendapat serta menjawab pertanyaan.

\section{Saran}

Saran yang dapat peneliti sampaikan pada skripsi ini berkenaan dengan kemampuan berpikir kritis siswa, guru dapat menerapkan big book pada mata pelajaran lain (tidak hanya IPS) untuk meningkatkan kemampuan berpikir kritis siswa, karena berdasarkan hasil penelitian pada skripsi ini, dengan menggunakan big book dapat meningkatkan kemampuan berpikir kritis siswa.

\section{DAFTAR PUSTAKA}

Aunurrahman. 2013. Belajar dan pembelajaran. Bandung: Alfabeta.

Alwasilah, Chaedar. 2014. CTL Contextual Teaching \& Learning Menyediakan Kegiatan Belajar-Mengajar Mengasyikan dan Bermakna. Bandung: Kaifa.

Arief S Sadiman, dkk. 2008. Media Pendidikan. Jakarta: PT Raja Grafindo Persada.

Aries, Erna Febru dan Ari Dwi Haryono. 2012. Penelitian Tindakan Kelas. Yogyakarta: Aditya Media Publishing

Arikunto, Suharsimi. 2010. Prosedur Penilaian Suatu Pendekatan Praktik. Jakarta: PT Rineka Cipta.

Asyar.R dan Khairinal. 2010. Media Pembelajaran Sekolah Dasar. Jakarta: Gaung Persada. Djamarah, Saipul Bahri. 2002. Psikologi Belajar. Jakarta: PT Rineka Cipta.

Fahrudin Faiz. 2012. Thinking Skill (Pengantar menuju Berpikir Kritis). Yogyakarta: Suka PressUIN Sunan Kalijaga.

Fisher, Alec. 2009. Berpikir Kritis Sebuah Pengantar. Jakarta: Erlangga.

Khodijah, Nyanyu. 2014. Psikologi Pendidikan. Jakarta: PT Raja Grafindo Persara.

Kowiyah. 2012. Meneingkatkan Berpikir Kritis pada Pembelajaran Kemampuan Matematik Berbasis Masalah. Jurnal Edukasi.Vol.3,2012.

Kurniasih, Imas \& Berlin Sani. 2014. Implementasi Kurikulum 2013. Strategi Pembelajaran Berorientasi Standar Proses Pendidikan. Jakarta: Kencana Prenadamedia Group. 


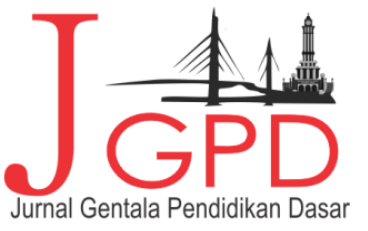

JURNAL geNTALA PENDIDIKAN DASAR Vol 4.No.2 December 2019 Page 245-263 P-ISSN : 2614-7092, E-ISSN : 2621-9611 Available Dnline at Web : http://anline-journal.unja.ac.id/index.php/gentala email : penyunting.jurnal.g-pgsd国unja.ac.id

Kurniawan, A. R. (2016). Pengembangan Perangkat Pembelajaran IPA berbasis Pendekatan Penemuan Terbimbing untuk Melatihkan Keterampilan Proses Siswa Sekolah Dasar. Jurnal Review Pendidikan Dasar: Jurnal Kajian Pendidikan Dan Hasil Penelitian, 2(2), 175-183.

Kurniawan, A. R., Noviyanti, S., \& Arsil, A. (2019). Optimasi Model Problem Based Learning Berbantuan Multimedia untuk Meningkatkan Keterampilan Kerja Tim di Sekolah Dasar. ELSE (Elementary School Education Journal): Jurnal Pendidikan dan Pembelajaran Sekolah Dasar, 3(2), 7-16.

Lynch.2008. A Guid For Using Big Book Clasroom. Jurnal Schlostic Canada Ltd. Hlm 1-6. Ma'rifah, Nurul. 2014. Peningkatan Kemampuan Berpikir Kritis Siswa Melalui Model Cooperative Tipe Think Pair Share Dalam Pembelajaran PKN Siswa Kelas V SDN 3 Puluhan Trucuk Klaten. Yogyakarta: Universitas Negeri Yogyakarta.

Mufidah, T. Nur. 2017. Peningkatan Kemampuan Membaca Pemahaman Melalui Media Big Book pada Siswa Kelas III SDN 1 Bero Klaten. Yogyakarta: Universitas Negeri Yogyakarta.

Nambiar,M.1993. Early Ready Instruction-Big Book in the ESL Classroom. Jurnal the English Teacher (vol XXII).Hlm.1-7.

Purwanto, Ngalim.1992.Psikologi Pendidikan. Bandung: PT Remaja Rosdakarya.

Riyanto, Yatim.2014. Paradikma Baru Pembelajaran. Jakarta: Kencana.

Sholeh, M. (2019). PENGEMBANGAN MEDIA POP-UP BOOK BERBASIS BUDAYA LOKAL KEBERAGAMAN BUDAYA BANGSAKU SISWA KELAS IV SEKOLAH DASAR. Jurnal Gentala Pendidikan Dasar, 4(1), 131-143.

Suyono dan Hariyanto.2011. Belajar dan Pembalajaran. Bandung: PT Remaja Rosdakarya.

Supriya. 2009. Pendidikan IPS. Bandung: PT Remaja Rosdakarya.

SyaifulBahri, Djamarah. 2002. Psikologi Belajar. Jakarta: PT Rineka Cipta.

Syah, Muhabbin. 2015. Psikologi Pendidikan Dengan Pendekatan Baru. Bandung: Remaja Rosdakarya

Umedi, Hadiyanto, Siswantari.2009. Manajemen Berbasis Sekolah. Jakarta: Universitas Terbuka.

USAID.2014. Buku Sumber untuk Dosen LPTK: Pembelajaran Literasi Kelas Awal di LPTK. Jakarta: USAID. 